\title{
The $\mathrm{G}_{\mathrm{q}} / \mathrm{G}_{11}$-mediated signaling pathway is critical for autocrine potentiation of insulin secretion in mice
}

\author{
Antonia Sassmann, ${ }^{1,2}$ Belinda Gier, ${ }^{3}$ Hermann-Josef Gröne, ${ }^{4}$ Gisela Drews, ${ }^{3}$ \\ Stefan Offermanns, ${ }^{1,2}$ and Nina Wettschureck ${ }^{1,2}$ \\ 'Department of Pharmacology, Max-Planck-Institute for Heart and Lung Research, Bad Nauheim, Germany. ${ }^{2}$ Institute of Pharmacology, \\ University of Heidelberg, Heidelberg, Germany. ${ }^{3}$ nstitute of Pharmacy, University of Tübingen, Tübingen, Germany. \\ ${ }^{4}$ German Cancer Research Center, Heidelberg, Germany.
}

\begin{abstract}
A variety of neurotransmitters, gastrointestinal hormones, and metabolic signals are known to potentiate insulin secretion through GPCRs. We show here that $\beta$ cell-specific inactivation of the genes encoding the $\mathrm{G}$ protein $\alpha$-subunits $\mathrm{G} \alpha_{\mathrm{q}}$ and $\mathrm{G} \alpha_{11}$ resulted in impaired glucose tolerance and insulin secretion in mice. Interestingly, the defects observed in $\mathrm{G} \alpha_{\mathrm{q}} / \mathrm{G} \alpha_{11}$-deficient $\beta$ cells were not restricted to loss of muscarinic or metabolic potentiation of insulin release; the response to glucose per se was also diminished. Electrophysiological recordings revealed that glucose-induced depolarization of isolated $\beta$ cells was impaired in the absence of $\mathrm{G} \alpha_{\mathrm{q}} / \mathrm{G} \alpha_{11}$, and closure of $\mathrm{K}_{\mathrm{ATP}}$ channels was inhibited. We provide evidence that this reduced excitability was due to a loss of $\beta$ cell-autonomous potentiation of insulin secretion through factors cosecreted with insulin. We identified as autocrine mediators involved in this process extracellular nucleotides such as uridine diphosphate acting through the $\mathrm{G}_{\mathrm{q}} / \mathrm{G}_{11}$-coupled P2Y6 receptor and extracellular calcium acting through the calciumsensing receptor. Thus, the $\mathrm{G}_{\mathrm{q}} / \mathrm{G}_{11}$-mediated signaling pathway potentiates insulin secretion in response to glucose by integrating systemic as well as autocrine/paracrine mediators.
\end{abstract}

\section{Introduction}

The adequate secretion of insulin from pancreatic $\beta$ cells is essential for the maintenance of normoglycemia; impaired insulin secretion results in diabetes mellitus with hyperglycemia, dyslipidemia, and consequent long-term tissue damage (1). The on-demand release of insulin from $\beta$ cells is mainly regulated by blood glucose levels: high concentrations of glucose result in enhanced intracellular glucose metabolism with accumulation of ATP and consecutive closure of ATP-sensitive $\mathrm{K}^{+}$channels, leading to the opening of voltage-operated $\mathrm{Ca}^{2+}$ channels and $\mathrm{Ca}^{2+}$-mediated exocytosis of insulin-containing vesicles $(2,3)$.

While the ATP-dependent mechanism is clearly the master regulator of insulin release, various mediators potentiate insulin release in response to glucose. For example, gastrointestinal hormones such as glucose-dependent insulinotropic polypeptide (GIP) or glucagon-like peptide-1 (GLP-1) potentiate insulin secretion by activation of GPCRs, which signal through the $G_{s}$ family of heterotrimeric $G$ proteins (4-6). The potentiating effect of $G_{s}$ on glucose-induced insulin release depends on activation of adenylyl cyclase and consecutive phosphorylation of voltage-operated $\mathrm{Ca}^{2+}$ channels $(7,8)$ or opening of nonselective cation channels $(9)$.

Another important group of modulators are neurotransmitters and neuropeptides $(10,11)$, most prominent among them being the neurotransmitter acetylcholine, which is released from vagal nerve terminals and potentiates insulin secretion through the muscarinic receptor subtype $\mathrm{M}_{3}(12-15)$. In contrast to the receptors for GIP and GLP-1, the $\mathrm{M}_{3}$ receptor does not elicit $\mathrm{G}_{\mathrm{s}^{-}}$ mediated adenylyl cyclase activation, but was shown to signal through the $\mathrm{G}_{\mathrm{q}} / \mathrm{G}_{11}$ family of heterotrimeric $\mathrm{G}$ proteins. The two

Conflict of interest: The authors have declared that no conflict of interest exists. Citation for this article: J Clin Invest. 2010;120(6):2184-2193. doi:10.1172/JCI41541. main members of the $\mathrm{G}_{\mathrm{q}} / \mathrm{G}_{11}$ family, $\mathrm{G}_{\mathrm{q}}$ and $\mathrm{G}_{11}$, are ubiquitously expressed $(16,17)$; their activation results in stimulation of phospholipase C $\beta$ (PLC $\beta$ ) isoforms and consequent inositol 1,4,5-trisphosphate-mediated ( $\mathrm{IP}_{3}$-mediated) intracellular calcium mobilization and PKC activation (18). Interestingly, $\beta$ cells express in addition to $\mathrm{M}_{3}$ a wide variety of other potentially $\mathrm{G}_{\mathrm{q}} / \mathrm{G}_{11}$-coupled receptors (19-21), and most of these receptors have been shown to be involved in the potentiation of insulin secretion, such as receptors for fatty acids (22), cholecystokinin (23), arginine vasopressin $(24,25)$, endothelin (26), extracellular nucleotides $(27,28)$, calcium (29), or zinc (30). Though for many of these receptors, the physiological relevance in the regulation of insulin secretion is unclear, the sheer number of potentially $G_{q} / G_{11}$-coupled receptors expressed in $\beta$ cells suggests an important role of this $G$ protein family in regulation of $\beta$ cell function. However, due to the lack of $\beta$ cell-specific inhibitors of $\mathrm{G}_{\mathrm{q}} / \mathrm{G}_{11}$, and due to the embryonic lethality of mice that lack the $\alpha$-subunits of $G_{q}$ and $G_{11}, G \alpha_{q}$ and $\mathrm{G \alpha}_{11}(31)$, the in vivo functions of $\mathrm{G}_{\mathrm{q}} / \mathrm{G}_{11}$ in insulin secretion have not been studied so far.

In order to investigate the role of the $\mathrm{G}_{\mathrm{q}} / \mathrm{G}_{11}$-mediated signaling pathway in the regulation of insulin secretion in vivo, we generated and studied mice with $\beta$ cell-specific knockout of the genes encoding $G \alpha_{q}$ and $G \alpha_{11}$. We show here that, in addition to their role in vagal and metabolic potentiation, $G \alpha_{q}$ and $G \alpha_{11}$ are required for a $\beta$ cell-autonomous feedback loop in which cosecreted factors such as nucleotides or calcium potentiate glucose-induced insulin secretion through $\mathrm{G}_{\mathrm{q}} / \mathrm{G}_{11}$-coupled receptors.

\section{Results}

Characterization of $\beta$ cell-specific $G \alpha_{q} / G \alpha_{11}$-deficient mice. To generate $\beta$ cell-specific $G \alpha_{q} / G \alpha_{11}$-deficient mice, we crossed the RipCre mouse line (32) with mice carrying floxed alleles of the gene cod- 
A

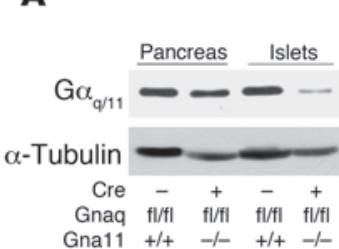

B

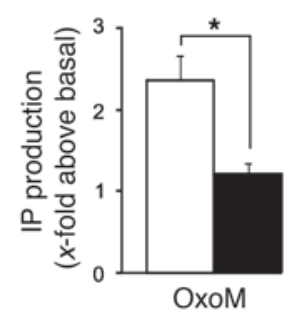

C

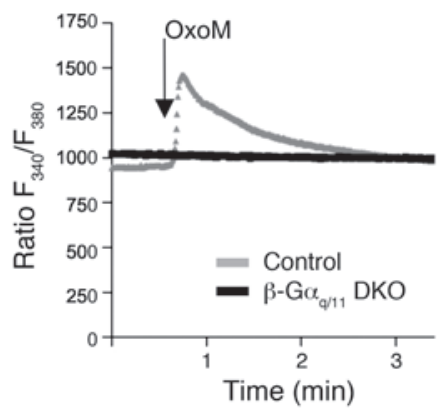

D

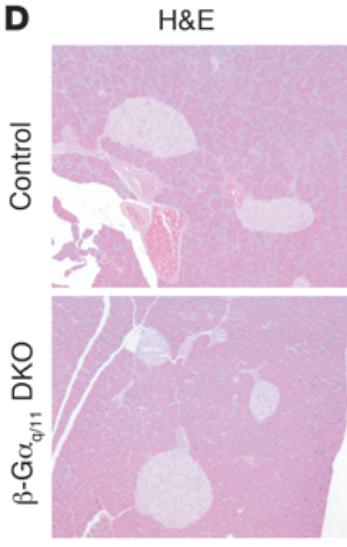

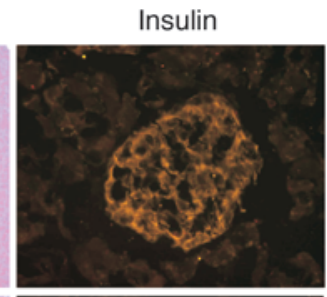
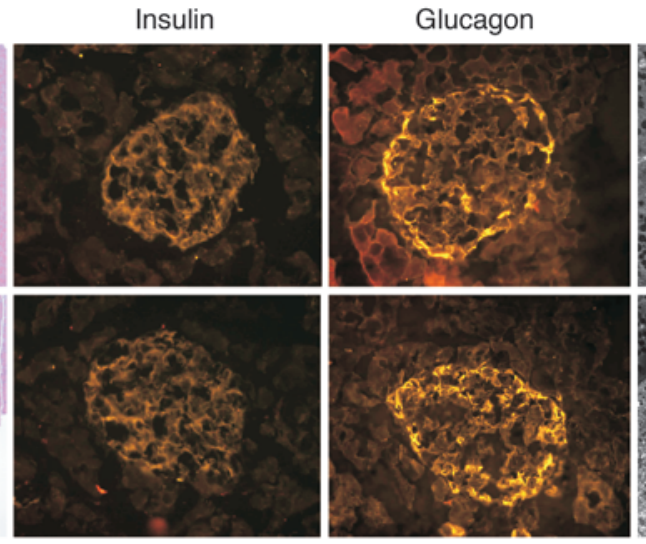
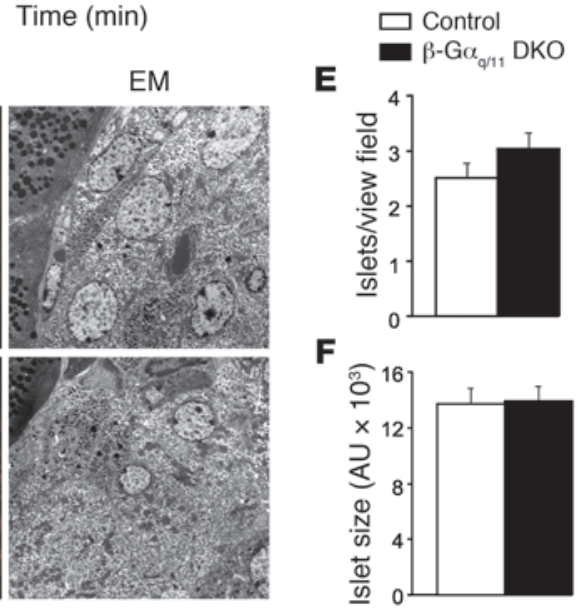

Figure 1

Characterization of $\beta$ cell-specific $G \alpha_{q} / G \alpha_{11}$-deficient mice. (A) Western blots of extracts of whole pancreas or isolated islets probed with antibodies directed against $\mathrm{G} \alpha_{q} / G \alpha_{11}$ or against $\alpha$-tubulin as loading control. (B) OxoM-induced (50 $\left.\mu \mathrm{M}\right)$ production of IPs in control (white) and $\mathrm{G}_{\mathrm{q}} / \mathrm{G}_{11}$-deficient (black) $\beta$ cells ( $n=3$ independent experiments). (C) Intracellular calcium mobilization in response to OxoM $(50 \mu \mathrm{M})$ in Fura-2/AM-loaded control and mutant $\beta$ cells. (D) Exemplary microphotographs of histological (original magnification, $\times 100)$ and immunohistochemical stainings $(\times 200)$ as well as electron microscopic sections $(E M, \times 3,000)$ of pancreatic islets or individual $\beta$ cells from control and $\beta-G \alpha_{q} / G \alpha_{11}$-deficient mice. (E and $\left.\mathbf{F}\right)$ Quantification of the number $(\mathbf{E})$ and size $(\mathbf{F})$ of control and mutant islets $(4$ animals per group, 20 sections per animal). ${ }^{*} P \leq 0.05$.

ing for $G \alpha_{\mathrm{q}}$, Gnaq $\left(G n a q^{f l / f l}\right)(33)$, and constitutive $G \alpha_{11}$-deficient animals (Gna11-/-) (31). Such $\beta$ cell-specific $G \alpha_{\mathrm{q}} / \mathrm{G} \alpha_{11}$-double-

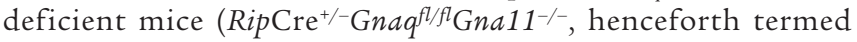
$\beta-G \alpha_{\mathrm{q}} / \mathrm{G}_{11}$ DKOs) were born at expected numbers and were viable and fertile. Their body weight did not differ from that of C57BL/ 6 wild-type mice or wild-type mice carrying the RipCre

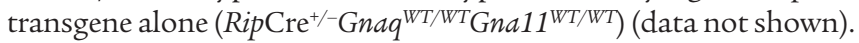
Since expression of the RipCre transgene has been reported to have metabolic effects per se (34), RipCre-positive animals were used as controls throughout the study. Western blotting of cholate extracts from controls and $\beta-G \alpha_{\mathrm{q}} / \mathrm{G} \alpha_{11}$ DKOs revealed only a mild decrease in $G \alpha_{q} / G \alpha_{11}$ immunoreactivity in whole pancreata but a strong reduction in $G \alpha_{q} / G \alpha_{11}$ in isolated islets (Figure 1A). The remaining immunoreactivity was most likely due to other endocrine cell types, for example, $\alpha, \delta$, or PP cells, or to endothelial cells. Since PLC $\beta$-mediated hydrolysis of phosphatidyl inositol-3,4-diphosphate $\left(\mathrm{PIP}_{2}\right)$ to $\mathrm{IP}_{3}$ and diacylglycerol (DAG) is the major cellular effect of $\mathrm{G} \alpha_{\mathrm{q}} / \mathrm{G \alpha}_{11}$ activation, we investigated inositol phosphate (IP) production and intracellular calcium mobilization in $\mathrm{G} \alpha_{\mathrm{q}} / \mathrm{G} \alpha_{11}$-deficient $\beta$ cells (Figure 1, B and C). Control islets responded to stimulation of muscarinic $\mathrm{M}_{3}$ receptors with oxotremorine $\mathrm{M}(\mathrm{OxoM})$ with a 2.4 -fold increase in IP production, which was almost abrogated in islets of $\beta-G \alpha_{q} / G \alpha_{11}$ DKOs (Figure 1B). As in the immunoblotting experiments, the remaining 1.2-fold increase in IP production was most likely due to other nonrecombined islet cell types. Fura-2-based imaging of intracellular calcium responses showed that calcium mobilization elicited by OxoM was abrogated in mutant $\beta$ cells (Figure 1C).

In order to investigate whether $\beta$ cell-specific inactivation of $G \alpha_{q} / G \alpha_{11}$ led to developmental abnormalities of pancreatic islets, we performed histological and immunohistochemical analyses. In neither H\&E-stained sections nor sections stained with antibodies directed against insulin, glucagon, or glucose transporter 2 did we detect differences between the genotypes (Figure 1D and data not shown). Also, using transmission electron microscopy, we did not find differences in $\alpha$ and $\beta$ cells, with $\beta$ cells showing characteristic granules with crystalline cores (Figure 1D). The average number of islets per section or the average size of islets also did not differ (Figure 1, E and F). The expression of islet-specific genes such as insulin, uncoupling protein 2 , glucose transporter 2 , glucokinase, or different transcription factors was not altered in mutant $\beta$ cells (Supplemental Figure 1; supplemental material available online with this article; doi:10.1172/JCI41541DS1).

$\beta$ Cell-specific $G \alpha_{q} / G \alpha_{11}$-deficient mice show impaired glucose tolerance and are diabetic. To assess the physiological role of $\mathrm{G} \alpha_{\mathrm{q}} / \mathrm{G} \alpha_{11}$ in $\beta$ cells, we determined blood glucose levels after oral and i.v. glucose challenge. $\beta-G \alpha_{q} / G \alpha_{11}$ DKOs showed in both tests significantly increased blood glucose levels throughout the test 
A

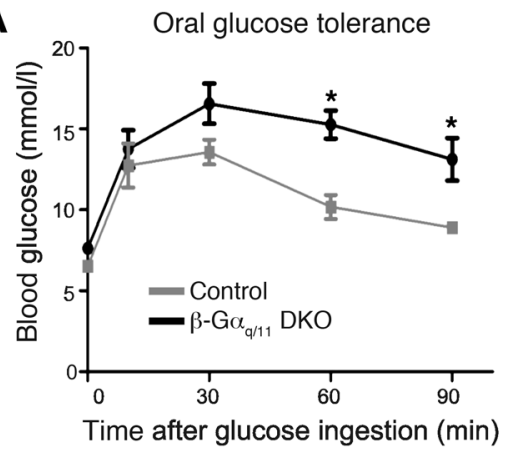

B

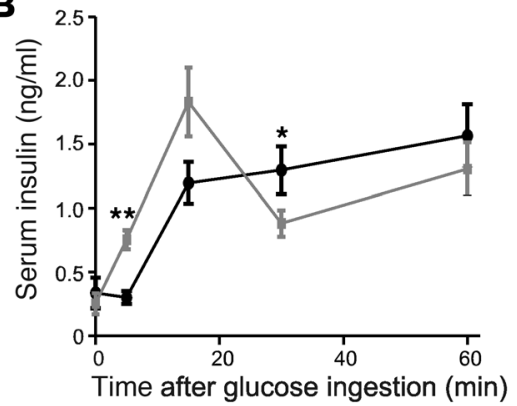

\section{C}
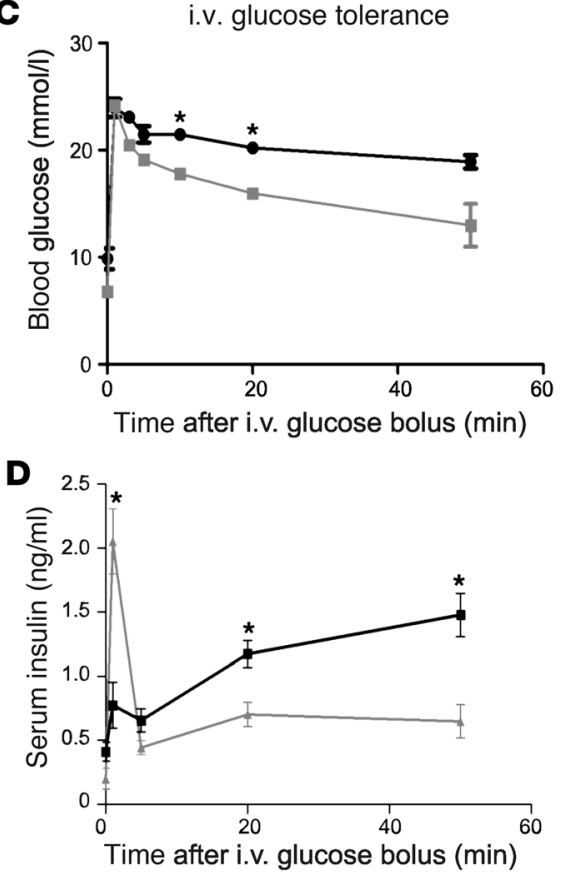
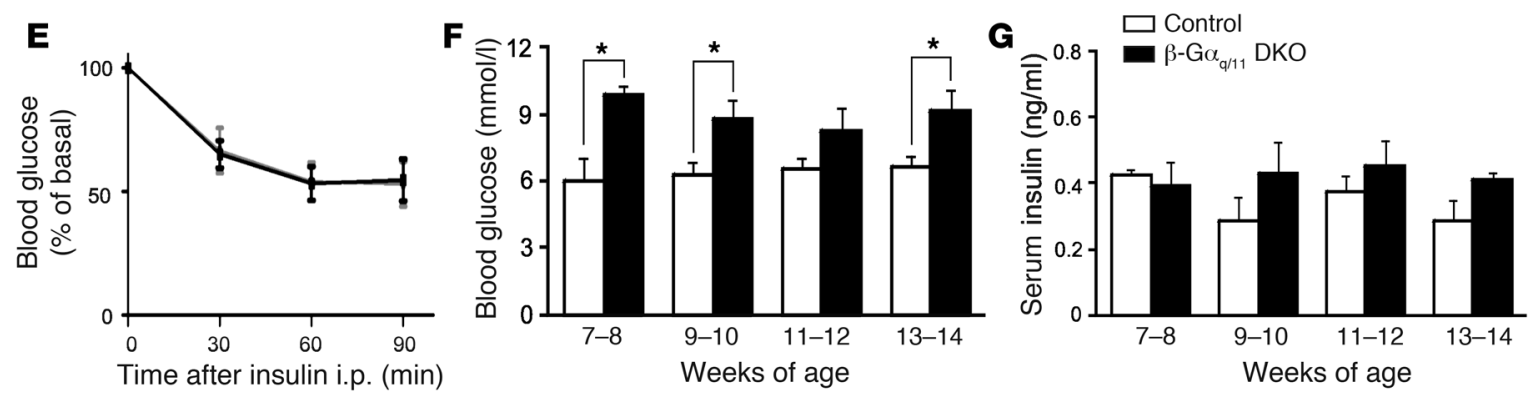

Figure 2

$\beta$ Cell-specific $G \alpha_{q} / G \alpha_{11}$-deficient mice show impaired glucose tolerance and are diabetic. (A and C) Blood glucose levels in control mice and $\beta-G \alpha_{q} / G \alpha_{11}$ DKOs following oral (2 mg/g body weight) (A) or i.v. (1 mg/g) (C) application of glucose $(n=8-10$ animals per group). (B and D) Serum insulin levels during oral (B) and i.v. (D) glucose tolerance testing ( $n=10$ animals per group for oral tests, $n=4-6$ for i.v. tests). (E) Blood glucose levels in control mice (gray triangles) and $\beta-G \alpha_{q} / G \alpha_{11}$ DKOs (black squares) after application of $0.5 \mathrm{U} / \mathrm{kg}$ body weight insulin intraperitoneally (insulin tolerance test) ( $n=5$ animals per group). ( $\mathbf{F}$ and $\mathbf{G}$ ) Blood glucose levels $(\mathbf{F})$ and serum insulin levels $(\mathbf{G})$ in fasted control mice and $\beta-G \alpha_{q} / G \alpha_{11}$ DKOs at different ages $\left(n=4-6\right.$ animals per group). ${ }^{\star} P \leq 0.05,{ }^{\star *} P \leq 0.005$.

period (Figure 2, A and C). We analyzed insulin levels during oral and i.v. glucose tolerance tests and found that the first peak of glucose-induced insulin secretion was significantly reduced in mutant animals (Figure 2, B and D). The first peak of insulin secretion is known to be crucial for a rapid suppression of hepatic glucose production (35); we therefore hypothesized that the impaired early insulin surge in $\beta-G \alpha_{q} / G \alpha_{11}$ DKOs is the basis of prolonged hyperglycemia in later phases. Since insulin-mediated reduction of hepatic glucose output is, at least partly, due to insulin-dependent suppression of glucagon secretion from pancreatic $\alpha$ cells $(36,37)$, we investigated glucagon serum levels after i.v. glucose challenge. These experiments showed that suppression of glucagon levels was impaired in $\beta-G \alpha_{q} / G \alpha_{11}$ DKOs (Supplemental Figure 2), suggesting that uncurbed hepatic glucose output contributes to prolonged hyperglycemia in these mice. Interestingly, the impairment of insulin secretion in mutant mice was only observed during the early phase of glu- cose tolerance tests; at later time points it was enhanced, most likely in response to the prolonged hyperglycemia. In order to exclude peripheral insulin resistance as a contributing factor, we performed insulin tolerance tests but did not detect any differences between the genotypes (Figure 2E).

We next investigated whether hyperglycemia was observed only after glucose challenge or also in the basal state. We found that at all ages investigated, $\beta-G \alpha_{q} / G \alpha_{11}$ DKOs were hyperglycemic compared with control animals after overnight fasting (Figure 2F). Basal insulin levels after overnight fasting were mildly but not significantly increased in $\beta-G \alpha_{q} / G \alpha_{11}$ DKOs (Figure $2 \mathrm{G}$ ). Blood glucose levels and insulin sensitivity of $\mathrm{G \alpha}_{11}$-single-deficient mice did not differ from those of wild-type animals (data not shown).

Loss of $G \alpha_{q} / G \alpha_{11}$ impairs glucose-induced insulin secretion in isolated islets. To investigate the underlying mechanisms of impaired glucose tolerance and reduced insulin secretion in $\beta-G \alpha_{q} / G \alpha_{11}$ DKOs, we studied insulin secretion in perifused islets in vitro. We 
A

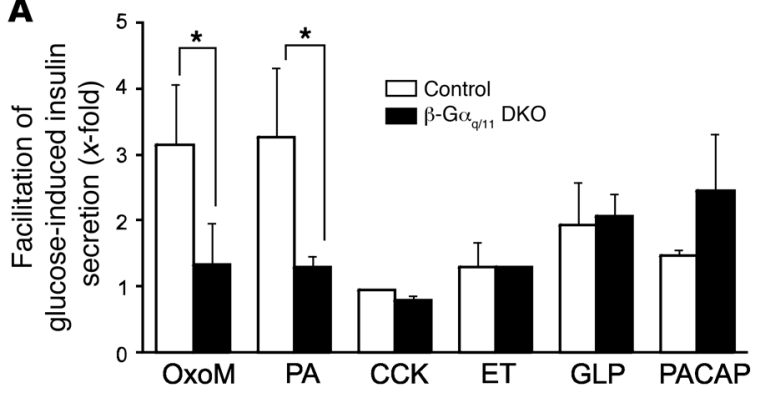

B

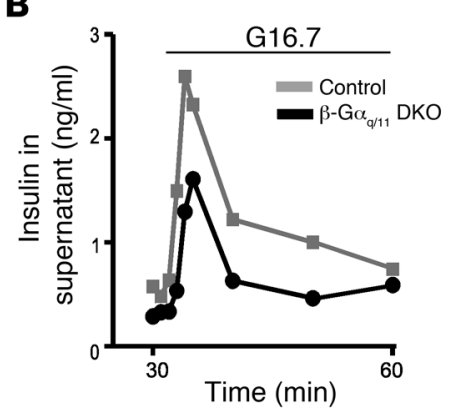

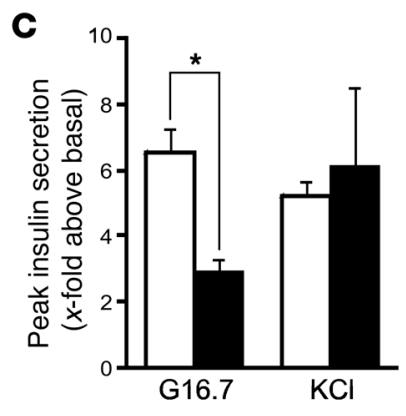

Figure 3

Loss of $\mathrm{G} \alpha_{q} / \mathrm{G}_{11}$ impairs not only agonist-induced potentiation but also glucose-induced insulin secretion per se. (A) Potentiation of glucoseinduced insulin secretion from perifused control islets and islets from $\beta-G \alpha_{q} / G \alpha_{11}$ DKOs by OxoM (50 $\left.\mu M\right)$, palmitic acid (PA), cholecystokinin-8 (CCK), endothelin-1 (ET), GLP-1 (100 $\mu \mathrm{M}$ each), or PACAP (10 nM) $(n=3-5$ independent experiments). Data are expressed as $x$-fold above insulin secretion induced by $16.7 \mathrm{mM}$ glucose alone. (B) Example of insulin secretion from perifused islets of control mice and $\beta$-G $\alpha_{q} / \mathrm{G}_{11}$ DKOs in response to $16.7 \mathrm{mM}$ glucose (G16.7). (C) Quantification of the maximal stimulatory effect of $16.7 \mathrm{mM} \mathrm{glucose}$ or $40 \mathrm{mM} \mathrm{KCl}$ on insulin secretion from perifused control and mutant islets $(n=5-6$ independent experiments). Data are expressed as $x$-fold above insulin secretion at $2.8 \mathrm{mM}$ glucose. ${ }^{\star} P \leq 0.05$.

found that the potentiating effect of OxoM on glucose-induced insulin secretion was almost completely abrogated (Figure 3A). In addition, the potentiating effect of palmitic acid, an agonist of the receptor GPR40, was also strongly impaired (Figure 3A). Other mediators that have been suggested to contribute to insulin secretion through potentially $\mathrm{G}_{\mathrm{q}} / \mathrm{G}_{11}$-coupled receptors, such as cholecystokinin or endothelin, did not significantly affect glucose-induced insulin secretion in control or mutant $\beta$ cells. The effects of agonists of $\mathrm{G}_{\mathrm{s}}$-coupled receptors, for example, pituitary adenylate cyclase-activating polypeptide (PACAP) or GLP-1, were not altered in $G \alpha_{q} / G \alpha_{11}$-deficient $\beta$ cells (Figure $3 \mathrm{~A}$ ).

Surprisingly, glucose-induced insulin secretion per se was significantly reduced in perifused islets from $\beta-G \alpha_{q} / G \alpha_{11}$ DKOs (Figure 3, B and C). This was not due to a general reduction in the secretory ability of $G \alpha_{q} / G \alpha_{11}$-deficient cells, since potassium chloride-mediated depolarization resulted in normal insulin secretion (Figure 3C). These data show that $\mathrm{G} \alpha_{q} / \mathrm{G \alpha}_{11}$ is required for full glucose-induced insulin secretion independent of potentiating signals produced by other cell types.

Impaired glucose-induced depolarization and $K_{A T P}$ channel closure in $G \alpha_{q} / G \alpha_{11}$-deficient $\beta$ cells. In order to study the mechanisms that underlie impaired glucose-induced insulin release, we investigated the electrophysiological properties of isolated $\beta$ cells from control and mutant animals. We compared the responses of control and $\mathrm{G} \alpha_{q} / G \alpha_{11}$-deficient $\beta$ cells to two glucose concentrations around the threshold ( 6 and $8 \mathrm{mM}$ glucose) and found that at both concentrations, the percentage of depolarized cells that elicited action potentials was lower in the $\mathrm{G} \alpha_{q} / \mathrm{G \alpha}_{11}$-defi-
A
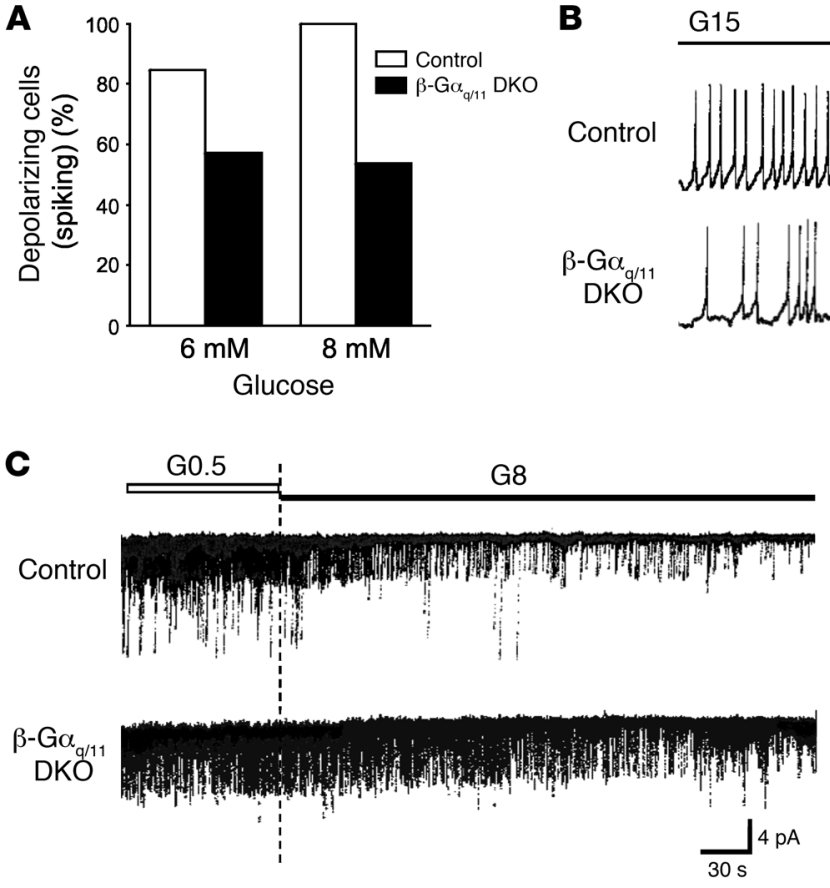

B $\quad$ G15

Control
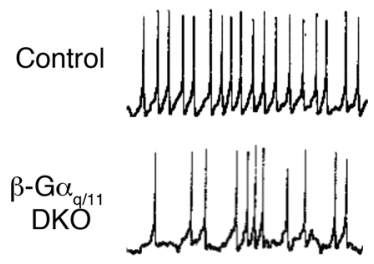

$\mathrm{J}_{2 \mathrm{~s}} 20 \mathrm{mV}$
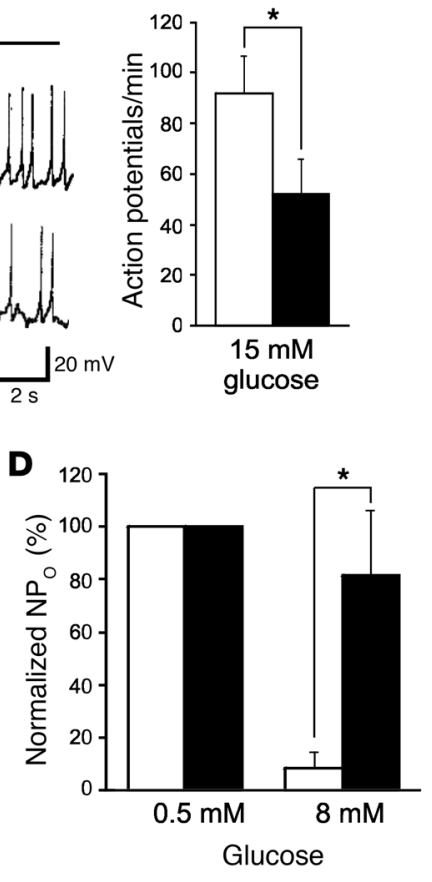

Figure 4

Impaired glucose-induced depolarization and $\mathrm{K}_{\mathrm{ATP}}$ channel closure in $\mathrm{G} \alpha_{q} / \mathrm{G}_{11}$-deficient $\beta$ cells. (A) Percentage of depolarized cells that elicited action potentials at 2 glucose concentrations ( 6 and $8 \mathrm{mM}$ glucose) around the threshold. For $\mathbf{A}$ and $\mathbf{B}$, membrane potential was recorded in the current-clamp mode with the perforated-patch technique. (B) Exemplary recording (left) and statistical evaluation (right) of action potential frequency at $15 \mathrm{mM}$ glucose in control and mutant $\beta$ cells. (C and D) Exemplary recordings (C) and statistical evaluation (D) of the effect of an augmentation of the glucose concentration from $0.5 \mathrm{mM}$ to $8 \mathrm{mM}$ on $\mathrm{K}_{\text {ATP }}$ activity in control and mutant $\beta$ cells. Single-channel recordings were performed in the cell-attached mode. Data in $\mathbf{D}$ are expressed as percentage of open probability in $0.5 \mathrm{mM}$ glucose $(100 \%)$ for each genotype. ${ }^{*} P \leq 0.05$. 

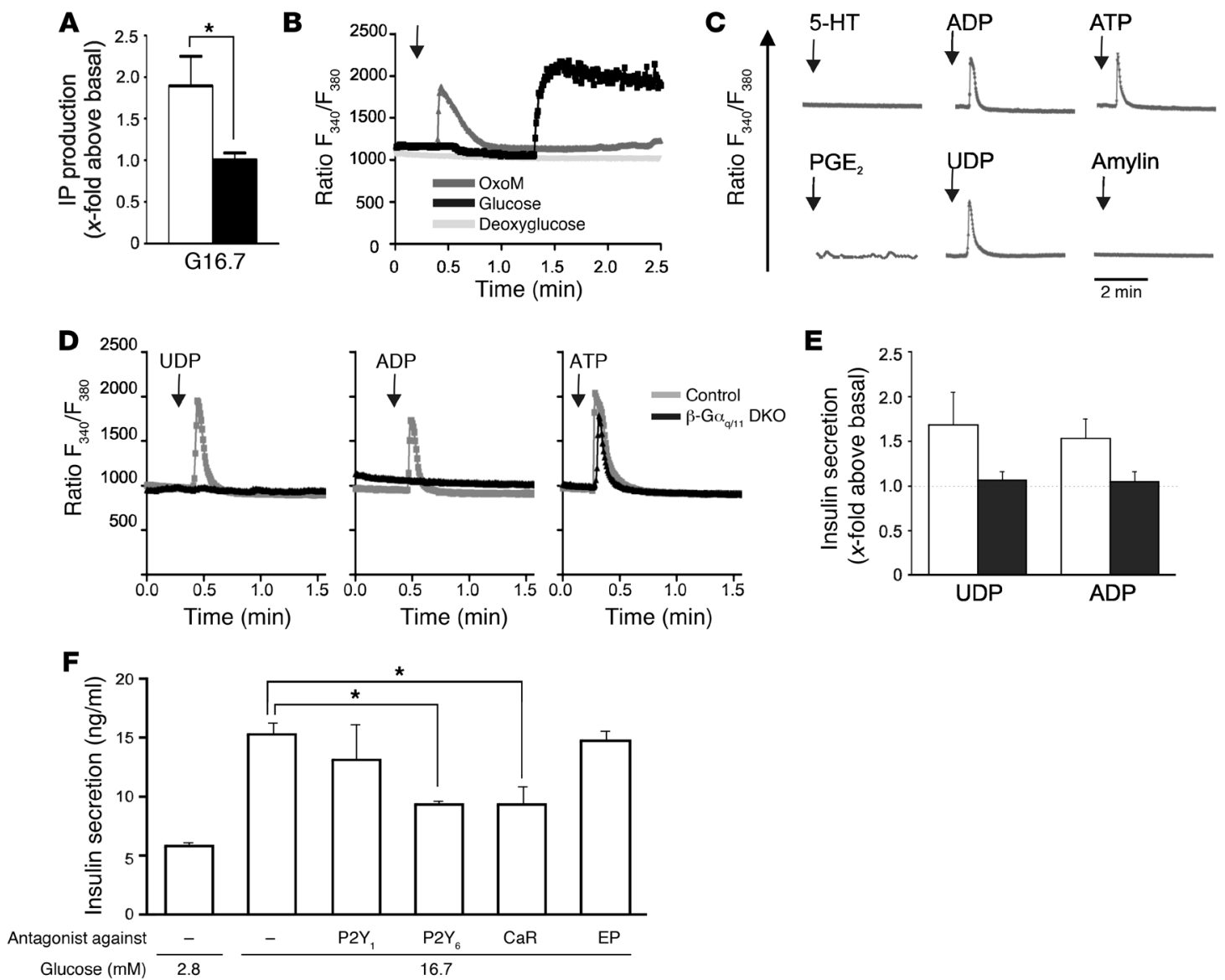

\section{Figure 5}

Cosecreted factors potentiate insulin secretion in a $\mathrm{G} \alpha_{q} / G_{\alpha_{11}}$-dependent manner. (A) IP production in control (white) and $\mathrm{G} \alpha_{q} / \mathrm{G}_{11}$-deficient (black) islets in response to an increase in glucose from $2.8 \mathrm{mM}$ to $16.7 \mathrm{mM}$ ( $n=4$ independent experiments). (B) Intracellular calcium mobilization in control $\beta$ cells elicited by $16.7 \mathrm{mM}$ glucose, $50 \mu \mathrm{M}$ OxoM, or $16.7 \mathrm{mM}$ 2-deoxyglucose. The arrow indicates the time point of application; before application, cells were kept at $5 \mathrm{mM}$ glucose. (C) Calcium mobilization in isolated Fura-2/AM-loaded control $\beta$ cells in response to different mediators known to be released from glucose-stimulated $\beta$ cells (ADP and ATP, $100 \mu \mathrm{M}$ each; serotonin [5-HT], amylin, and prostaglandin $\mathrm{E}_{2}$ [PGE 2 ], $1 \mu \mathrm{M}$ each; UDP, $\left.200 \mu \mathrm{M}\right)$. (D) Calcium mobilization in isolated Fura-2/AM-loaded control and mutant $\beta$ cells in response to the nucleotides UDP, ADP, and ATP. Data are presented as the $340 / 380 \mathrm{~nm}$ fluorescence ratio $\left(\right.$ Ratio $\left.F_{340} / F_{380}\right)$. $(E)$ Stimulation of insulin secretion in control (white) and mutant (black) $\beta$ cells in response to UDP and ADP (data expressed as $x$-fold of basal secretion) ( $n=5-6$ per group). (F) Insulin secretion of control islets in response to $16.7 \mathrm{mM}$ glucose in the absence or presence of antagonists directed against different GPCR subtypes (data represent insulin concentration in the supernatant of 20 islets after 30 minutes of static incubation) ( $n=4$ independent experiments). ${ }^{\star} P \leq 0.05$.

cient cell population (Figure 4A). Also, at high glucose concentrations, the frequency of action potentials was reduced in mutant cells (Figure 4B).

Since $\beta$ cell depolarization in response to glucose is mainly mediated by ATP-dependent closure of ATP-sensitive $\mathrm{K}^{+}\left(\mathrm{K}_{\mathrm{ATP}}\right)$ channels $(2,3)$, we studied the electrophysiological properties of $\mathrm{K}_{\mathrm{ATP}}$ in control and mutant cells. While we did not find significant differences in $\mathrm{K}_{\mathrm{ATP}}$ channel open probability at low glucose concentrations $(0.5 \mathrm{mM})$, the responses at $8 \mathrm{mM}$ glucose differed significantly between the genotypes: control cells responded to the elevation of glucose concentration with a significant reduction in open probability of $\mathrm{K}_{\mathrm{ATP}}$ channels, and this response was strongly impaired in $G \alpha_{q} / G \alpha_{11}$-deficient $\beta$ cells (Figure $4, C$ and D). These findings show that glucose/ATP-dependent closure of $\mathrm{K}_{\mathrm{ATP}}$ channels is impaired in the absence of $G \alpha_{q} / G \alpha_{11}$, resulting in a reduced responsiveness toward glucose.
Cosecreted factors potentiate insulin secretion in a $G \alpha_{q} / G \alpha_{11}$-dependent manner. PLC $\beta$-mediated hydrolysis of $\mathrm{PIP}_{2}$ is the major effector pathway of activated $G_{q} / G_{11}$ (38), and PIP $P_{2}$ has been suggested to take part in the regulation of $\mathrm{K}_{\mathrm{ATP}}$ channels (39, $40)$. We therefore hypothesized that glucose application activates by a yet-to-be defined pathway, $G \alpha_{q} / G \alpha_{11}$, leading to PIP hydrolysis and facilitation of $\mathrm{K}_{\mathrm{ATP}}$ channel closure. To test this hypothesis, we determined glucose-induced IP production in the presence and absence of $G \alpha_{q} / G \alpha_{11}$. We found that glucose induced a 1.85-fold increase in IP production in isolated control islets and that this effect was abrogated in islets of $\beta-G \alpha_{q} / G \alpha_{11}$ DKOs (Figure 5A). Glucose-induced, G $\alpha_{q} / G \alpha_{11}$-mediated PIP 2 hydrolysis might be mediated by different mechanisms: direct activation of $\mathrm{G}_{\mathrm{q}} / \mathrm{G}_{11}$-coupled receptor by glucose; or glucoseinduced release of an autocrine mediator, which in turn acts on a $G_{q} / G_{11}$-coupled receptor. To test the possibility that glucose 
directly activates a $G_{q} / G_{11}$-coupled receptor, we compared the kinetics of intracellular calcium mobilization in response to OxoM with the calcium mobilization elicited by glucose. While OxoM induced the fast and short-lived calcium response typi-

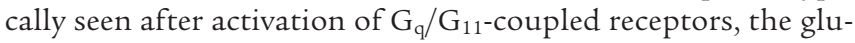
cose-induced response was slower and longer-lived (Figure 5B). What is more, this calcium response depended on intracellular glucose metabolism, since the non-metabolizable glucose derivative 2-deoxyglucose did not evoke any response (Figure 5B). We concluded from these experiments that glucose does not directly activate a $G_{q} / G_{11}$-coupled receptor and instead focused on the second possibility, the release of a soluble mediator from glucose-stimulated $\beta$ cells.

$\beta$ Cells are known to cosecrete with insulin a variety of substances that can act as agonists of GPCRs, for example, serotonin, nucleotides, amylin, or bivalent cations (41-43); in addition, they produce and release prostaglandins upon glucose stimulation (44). In order to investigate which of these mediators are able to potentiate $\beta$ cell activation in a $G \alpha_{q} / G \alpha_{11}$-dependent manner, we studied calcium mobilization in isolated $\beta$ cells at sub-threshold glucose levels (Figure 5, C and D). We found that the nucleotides adenosine diphosphate (ADP), uridine diphosphate (UDP), or ATP induced calcium mobilization in control $\beta$ cells, while other substances, such as serotonin or prostaglandin $E_{2}$ had no effect (Figure 5C). In $G \alpha_{q} / G \alpha_{11}$-deficient islets, calcium mobilization in response to UDP and ADP was abrogated, while the effect of ATP was preserved (Figure 5D). The normal calcium response to ATP is most likely due to the presence ATP-gated P2X ion channels (45). We next investigated whether UDP- and ADP-induced calcium mobilization was sufficient to trigger insulin release at threshold glucose levels and found that these nucleotides increased insulin secretion 1.75 -fold and 1.5 -fold in control islets, while their effects were abrogated in islets of $\beta-G \alpha_{q} / G \alpha_{11}$ DKOs (Figure $5 \mathrm{E}$ ).

Having established that UDP and ADP enhance calcium mobilization and insulin secretion in a $G \alpha_{\mathrm{q}} / \mathrm{G}_{11}$-dependent manner, we investigated whether this putative autocrine potentiation relevantly contributes to glucose-induced insulin secretion. To do so, and also to identify the GPCR subtypes involved in this feedback loop, we studied glucose-induced insulin secretion in isolated islets in the absence and presence of different GPCR antagonists (Figure 5F). Since murine $\beta$ cells have been shown to express the UDP receptor $\mathrm{P}_{2} \mathrm{Y}_{6}$ as well as the ADP/ATP receptor $\mathrm{P}_{2} \mathrm{Y}_{1}(19,27)$, we used the $\mathrm{P} 2 \mathrm{Y}_{1}$ receptor antagonist MRS2179 and the $\mathrm{P}_{2} \mathrm{Y}_{6}$ antagonist MRS2578 for this purpose. In vehicletreated control islets, elevation of glucose concentration from $2.8 \mathrm{mM}$ to $16.7 \mathrm{mM}$ resulted in a significant increase in insulin secretion. In the presence of the $\mathrm{P}_{2} \mathrm{Y}_{1}$ receptor antagonist MRS2179, glucose-induced insulin secretion was slightly but not significantly reduced, while blockade of $\mathrm{P}_{2} \mathrm{Y}_{6}$ by MRS 2578 significantly reduced insulin secretion in response to glucose (Figure 5F). To study the potential involvement of coreleased calcium or prostaglandins, we also applied antagonists of the calcium-sensing receptor and of prostaglandin $\mathrm{E}_{2}$ receptor subtypes, which have been shown to be expressed in murine $\beta$ cells and islets, respectively $(19,46)$. We found that blockade of the calcium-sensing receptor with antagonist NVP-CAR16 resulted in a significant reduction of insulin secretion, while blockade of prostaglandin receptors with AH 6809 had no effects. Neither NVP-CAR16 nor MRS2578 affected basal insulin secretion (data not shown), suggesting that these antagonists did not disturb islet function per se. We conclude from these experiments that nucleotides and calcium released from glucose-stimulated $\beta$ cells potentiate insulin release through the $G_{q} / G_{11}$-coupled receptors $\mathrm{P}_{2} \mathrm{Y}_{1}, \mathrm{P}_{2} \mathrm{Y}_{6}$, and $\mathrm{CaR}$, thereby contributing to adequate on-demand secretion of insulin.

\section{Discussion}

We show in this study that $\beta$ cell-specific inactivation of $G \alpha_{q} / G \alpha_{11}$ leads to hyperglycemia with a significant decrease in the early phase of insulin secretion in both oral and i.v. glucose tolerance tests. Since the first peak of insulin secretion is crucial for the efficient suppression of hepatic glucose production (35), the observed reduction of early insulin secretion most likely explains the prolonged hyperglycemia observed in mutant mice.

The impairment of oral glucose tolerance is probably partly due to the loss of parasympathetic potentiation of insulin secretion, which is known to be mainly mediated by the $\mathrm{G}_{\mathrm{q}} / \mathrm{G}_{11}$-coupled muscarinic acetylcholine receptor $\mathrm{M}_{3}(10-13,47)$. In addition to abrogation of $\mathrm{M}_{3}$-mediated effects, impaired signaling through the fatty acid receptor GPR40 (48) might contribute to the impaired oral glucose tolerance in $\beta-G \alpha_{\mathrm{q}} / G \alpha_{11} \mathrm{DKOs}$, though the relevance of GPR40 in glucose-induced insulin secretion in vivo is still under debate (49-51).

In contrast to previous studies performed in isolated rat islets (52-54), our study did not reveal facilitation of insulin secretion in response to cholecystokinin-8, which might be partly due to species-specific differences in gene expression: The cholecystokinin receptor CCK-A has been shown to be highly expressed in rat islets (55), while expression in murine islets is - according to our own analyses (data not shown) and published data - weak to undetectable $(19,46,56)$. However, a mild facilitating effect of CCK at $8.3 \mathrm{mM}$ glucose has been described by others (57), and we therefore hypothesize that CCK mediates a weak facilitation at low to intermediate glucose levels, which is masked by the high glucose concentrations used in our experiments. In contrast to cholecystokinin-8, endothelin-1 elicited a weak (1.3-fold) facilitation of secretion at $16.7 \mathrm{mM}$ glucose, which was not impaired in islets from $\beta-G \alpha_{q} / G \alpha_{11}$ DKOs. This finding might point to an involvement of other $G$ protein families besides $G_{q} / G_{11}$, for example, $G_{12} / G_{13}$, a $G$ protein family that has in other cell types been suggested to couple to the endothelin-1 receptor ET-A (58) and been implicated in regulation of secretion (59).

Interestingly, our results show that glucose-induced $\beta$ cell activation is disturbed even under conditions that exclude potentiating signals produced by other cell types, suggesting that inactivation of $\mathrm{G} \alpha_{\mathrm{q}} / \mathrm{G} \alpha_{11}$ impairs glucose sensitivity of $\beta$ cells per se. One possible explanation might be a disturbance of $\beta$ cell development as described in $\beta$ cell-specific $G \alpha_{\mathrm{s}}$-deficient mice (60), but we did not find differences in islet mass, number, histology, immunohistochemistry, electron microscopy, or the expression pattern of $\beta$ cell marker genes. What is more, insulin secretion in response to agonists of $\mathrm{G}_{\mathrm{s}}$-coupled receptors such as GLP-1 or PACAP did not differ between the genotypes, nor did the response to direct depolarization by potassium chloride. Our findings therefore show that $\mathrm{G} \alpha_{\mathrm{q}} / \mathrm{G} \alpha_{11}$ is not essential for $\beta$ cell development but makes a major contribution to the $\beta$ cell-autonomous regulation of glucose-induced insulin secretion.

Our electrophysiological data revealed an impaired responsiveness of mutant cells at threshold glucose concentrations, and 
even at maximal stimulation, the frequency of action potentials was reduced. As to the potential mechanism by which $G \alpha_{q} / G \alpha_{11}$ modulates $\beta$ cell excitability, our electrophysiological recordings suggest an altered glucose-dependent closure of the $\mathrm{K}_{\text {ATP }}$ channel. A possible connection between $\mathrm{G} \alpha_{\mathrm{q}} / \mathrm{G \alpha}_{11}$ and $\mathrm{K}_{\mathrm{ATP}}$ is local membrane phosphoinositide concentrations, especially those of $\mathrm{PIP}_{2}$, the most abundant phosphoinositide (61). Membrane-bound PIP was shown to increase the open probability and reduce the ATP sensitivity of $\mathrm{K}_{\mathrm{ATP}}$ channels $(39,40)$, thereby contributing to $\beta$ cell hyperpolarization. Upon activation of $\mathrm{G}_{\mathrm{q}} / \mathrm{G}_{11}$-coupled receptors, $\mathrm{PIP}_{2}$ is hydrolyzed to $\mathrm{IP}_{3}$ and DAG (38), and the local reduction of membrane $\mathrm{PIP}_{2}$ was suggested to facilitate $\mathrm{K}_{\mathrm{ATP}}$ channel closure and cellular depolarization (62). Reduced $G \alpha_{q} / G \alpha_{11}$-mediated $\mathrm{PIP}_{2}$ hydrolysis might accordingly result in impaired $\mathrm{K}_{\mathrm{ATP}}$ channel closure and reduced $\beta$ cell depolarization. However, in addition to $\mathrm{PIP}_{2}$-mediated modulation of $\mathrm{K}_{\mathrm{ATP}}$ channel open probability, other $\mathrm{G}_{\mathrm{q}} / \mathrm{G}_{11}$-mediated effects such as intracellular $\mathrm{Ca}^{2+}$ mobilization (63-65) or PKC activation (66) might contribute to $\mathrm{G} \alpha_{\mathrm{q}} /$ $\mathrm{G} \alpha_{11}$-mediated potentiation of insulin secretion.

An important question is certainly by which mechanism does glucose induce $\mathrm{G} \alpha_{\mathrm{q}} / \mathrm{G \alpha}_{11}$-mediated phosphoinositide hydrolysis. It has long been known that glucose can stimulate IP production in pancreatic islets $(67,68)$, but neither we nor others $(69)$ have found evidence for an involvement of a glucose-activated plasma membrane receptor. Instead, it was suggested that the glucose-induced phosphoinositide response might be triggered by the accompanying increase in calcium influx $(70,71)$. Our data, however, show that glucose-induced production of $\mathrm{IP}_{3}$ depends on $\mathrm{G} \alpha_{\mathrm{q}} / \mathrm{G} \alpha_{11}$, which led us to the hypothesis that mediators cosecreted with insulin might activate $G \alpha_{q} / G \alpha_{11}$ and potentiate insulin release in an autocrine feedback loop.

A variety of substances are known to be cosecreted with insulin or to be released upon glucose stimulation, such as nucleotides, bivalent cations, C-peptide, amylin, or prostaglandins (41). For example, $\beta$ cell vesicles contain $3.5 \mathrm{mM}$ ATP and $5 \mathrm{mM}$ ADP (41), and glucose stimulation releases ATP from a single pancreatic $\beta$ cell to a local extracellular ATP concentration exceeding $25 \mu \mathrm{M}$ (72). In addition, the pyrimidines UTP and UDP can be released in a controlled exocytotic fashion from various cell types (73-75). As to the effect of nucleotides on insulin secretion, both stimulation and inhibition have been described, depending on the nucleotide, tissue, and species tested $(27,45,76-81)$. Our own data clearly show that ADP and UDP potentiate insulin secretion in a $G \alpha_{q} /$ $\mathrm{G} \alpha_{11}$-dependent manner, while ATP-induced calcium responses are independent of $\mathrm{G} \alpha_{\mathrm{q}} / \mathrm{G} \alpha_{11}$, most likely mediated by ATP-gated P2X ion channels (45). With respect to the receptors involved in the autocrine potentiation of insulin secretion, we identified the UDP receptor $\mathrm{P}_{2} \mathrm{Y}_{6}$ as a major player, while the contribution of the $\mathrm{P}_{2} \mathrm{Y}_{1}$ receptor, which is activated by ADP and ATP, seems less prominent. In addition to $\mathrm{P} 2 \mathrm{Y}$ receptor subtypes, our data show an important role of the extracellular calcium-sensing receptor $\mathrm{CaR}$ in the potentiation of glucose-induced insulin secretion from isolated $\beta$ cells. In line with this finding, the calcimimetic $\mathrm{R}-568$, a substance that induces CaR activation already at calcium concentrations as low as $0.2 \mathrm{mM}$, was shown to increase insulin release from human islets and the murine $\beta$ cell line MIN6 (29), and shRNA-mediated knockdown of CaR in MIN6 pseudoislets impaired glucose-induced insulin secretion (82). Interestingly, combined application of NVP-CAR16 and MRS2578 did not result in further reduction of glucose-induced insulin secretion, suggest- ing that $\mathrm{P}_{2} \mathrm{Y}_{6}$ - and CaR-mediated signaling are not interchangeable and that concomitant activation of both receptors is required for full facilitation of insulin release.

Taken together, our data show that the $G_{q} / G_{11}$ family is crucial not only for neural and metabolic facilitation, but also for the $\beta$ cell-autonomous potentiation of glucose-induced insulin secretion by nucleotides and calcium cosecreted with insulin. Thus, given the multitude of potentiating signals that converge on $\mathrm{G}_{\mathrm{q}} / \mathrm{G}_{11}$, a direct pharmacological modulation of this signaling pathway in $\beta$ cells might in the future prove more efficient in enhancing insulin secretion than targeting individual GPCRs.

\section{Methods}

Materials. OxoM, palmitic acid, endothelin-1, GLP-1, PACAP, serotonin, ADP, ATP, UDP, prostaglandin $\mathrm{E}_{2}$, MRS2578, MRS2179, as well as $\alpha$-tubulin antibodies were from Sigma-Aldrich. Cholecystokinin-8 was from Bachem; antagonist AH 6809 was from Cayman. Antibodies against $G \alpha_{q}$ and $\mathrm{G \alpha}_{11}$ were from Santa Cruz Biotechnology Inc. The CaR antagonist NVPCAR16 was provided by Klaus Seuwen (Novartis, Basel, Switzerland).

Experimental animals. Animals were kept on a mixed C57BL/6 $\times 129 / \mathrm{Sv}$ background with a predominant contribution of the C57BL/ 6 strain and were housed under specific pathogen-free conditions. Animal experiments were approved by the Institutional Animal Care and Use Committee of the Regierungspräsidium Karlsruhe. Genotyping for $G n a q^{W T}$ and $G n a q^{l}$ alleles as well as for Gna11 ${ }^{W T}$ and $\mathrm{Gna} 11^{-}$alleles was performed as described previously (33). RipCre mice were obtained from Mark A. Magnuson, Vanderbilt University, Nashville, Tennessee, USA. Primers for the detection of the RipCre transgene were 5'-CTCTGGCCATCTGCTGATCC-3' and 5'-CGCCGCATAACCAGTGAAAC-3'. Mice were fed a standard pellet chow (ssniff) with water ad libitum. If not otherwise stated, experiments were performed in male mice at $12-16$ weeks of age.

Glucose tolerance tests and insulin tolerance tests. After overnight fasting, mice were anesthetized with pentobarbital, and glucose was administered either by oral gavage at a dose of $2 \mathrm{mg} / \mathrm{g}$ body weight or i.v. at a dose of $1 \mathrm{mg} / \mathrm{g}$. Blood samples were taken from the retroorbital plexus before and after glucose application at indicated time points. Serum glucose concentration was measured with the glucose hexokinase method (Randox Laboratories). Serum insulin concentrations were measured using the Sensitive Rat Insulin RIA Kit (Linco Research).

For insulin tolerance tests, mice were anesthetized after overnight fasting with pentobarbital, and $0.5 \mathrm{IU} / \mathrm{kg}$ insulin was injected intraperitoneally. Blood samples were taken from the retroorbital plexus before and 30, 60, and 90 minutes after insulin injection.

Histological, immunohistochemical, and electron microscopic analyses. $\mathrm{H} \& \mathrm{E}$ staining was performed on $4-\mu \mathrm{m}$ paraffin sections according to standard protocols. For immunohistochemical staining of pancreas sections, $18-\mu \mathrm{m}$ cryosections were fixed in acetone for 2 minutes, washed twice in PBS, blocked with $5 \%$ goat serum (Vector Laboratories) in PBS for 30 minutes, and incubated for 1 hour at room temperature or overnight at $4{ }^{\circ} \mathrm{C}$ with antibodies directed against insulin (Santa Cruz Biotechnology Inc.), glucagon (Linco Research), or GLUT2 (a gift from Bernard Thorens, University of Lausanne, Lausanne, Switzerland). Slides were washed twice in PBS and then incubated for 1 hour at room temperature with TRITC-anti-rabbit (Dako). After washing twice in PBS, slides were mounted in Mowiol (Calbiochem/EMD Biosciences) and analyzed on a Leica DC300F microscope by an experimenter blinded to genotype. For transmission electron microscopy, pancreata were fixed in Karnovsky's fixative, followed by postfixation in $2 \%$ osmium tetroxide and uranyl acetate. Tissues were then embedded in Araldite, and ultrathin sections were contrasted with lead ultrate, viewed with a Zeiss EM900, and photographed with a CCDA1 camera. 
Islet isolation and $\beta$ cell preparation. After animals were sacrificed by cervical dislocation, $3 \mathrm{ml}$ Krebs bicarbonate buffer $(11.5 \mathrm{mM} \mathrm{NaCl}, 0.47$ $\mathrm{mM} \mathrm{KCl}, 0.12 \mathrm{mM} \mathrm{KH}_{2} \mathrm{PO}_{4}, 0.12 \mathrm{mM} \mathrm{MgSO}_{4}, 0.256 \mathrm{mM} \mathrm{CaCl}_{2}, 20 \mathrm{mM}$ $\mathrm{NaHCO}_{3}, 10 \mathrm{mM}$ HEPES, supplemented with $5 \mathrm{mM}$ glucose, and $1 \mathrm{mg} /$ $\mathrm{ml} \mathrm{BSA}$ ) containing $1 \mathrm{mg}$ collagenase P (Roche Diagnostics) was injected into the common bile duct. The distended pancreas was removed and incubated in a shaking water bath for 15-20 minutes. Isolated islets were washed and picked under a dissecting microscope. For insulin secretion experiments, islets were kept overnight at $37^{\circ} \mathrm{C}, 5 \% \mathrm{CO}_{2}$ in RPMI-1640/ FBS/antibiotic solution. To produce clusters or single cells, freshly isolated pancreatic islets were incubated for 15 minutes in a calcium-free Krebs bicarbonate solution containing $0.5 \mathrm{mM}$ EDTA. Cells were seeded on a $3-\mathrm{cm}$ coverslip and cultured overnight at $37^{\circ} \mathrm{C}, 5 \% \mathrm{CO}_{2}$, in RPMI1640/FBS/antibiotic solution.

Insulin secretion during perifusion experiments and static incubation. For perifusion experiments, groups of 50 islets were placed in a perifusion chamber and continuously perifused with Krebs-bicarbonate buffer according to the following schedule: from minute 1 to 30 , perifusion with $2.8 \mathrm{mM}$ glucose (equilibration phase); minutes 31 to 60 , with $16.7 \mathrm{mM}$ glucose ("glucose-only" phase); minute 61 to 90 , with $2.8 \mathrm{mM}$ glucose (equilibration phase); minute 91 to 120 , with $16.7 \mathrm{mM}$ glucose plus different GPCR agonists (50 $\mu \mathrm{M}$ OxoM, $100 \mu \mathrm{M}$ palmitic acid, $100 \mathrm{nM}$ CCK-8, 100 nM endothelin, 100 nM GLP-1, 10 nM PACAP) ("agonist plus glucose" phase). The perifusate was collected every minute, and insulin content was measured with the Sensitive Rat Insulin RIA Kit. The potentiating effect of GPCR agonists was evaluated as the ratio of peak insulin secretion during the agonist plus glucose phase divided by peak secretion during the glucose-only phase.

For static incubation experiments, islets were placed in groups of 20 islets in a 24-well plate. After a 30-minute preincubation period at $2.8 \mathrm{mM}$ glucose, islets were stimulated for 10 minutes with $200 \mu \mathrm{M}$ UDP or $100 \mu \mathrm{M}$ $\mathrm{ADP}$ in the presence of $5 \mathrm{mM}$ glucose. Antagonists (MRS2179, MRS2578, AH 6809, NVP-CAR16, all $1 \mu \mathrm{M}$ ) were applied together with $16.7 \mathrm{mM}$ glucose for 30 minutes. The supernatant was removed and insulin content measured with the Sensitive Rat Insulin RIA Kit.

IP1 assay. For IP measurements, isolated islets were dispersed into single cells that were seeded on a 96-well plate and incubated overnight at $37^{\circ} \mathrm{C}$, $5 \% \mathrm{CO}_{2}$ in RPMI-1640/FBS/antibiotic solution. Before stimulation, cells were preincubated at $2.8 \mathrm{mM}$ glucose for 30 minutes. The stimulation period was 30 minutes using $16.7 \mathrm{mM}$ glucose or $50 \mu \mathrm{M}$ OxoM; sample collection and IP1 measurement were performed by ELISA (IP-One-ELISA, Cisbio) according to the manufacturer's instructions.

Measurement of intracellular $\left[\mathrm{Ca}^{2+}\right]$. For fluorescence-based imaging of $\left[\mathrm{Ca}^{2+}\right]$, isolated $\beta$ cells or islets were cultured on glass coverslips. Cells were loaded for 30 minutes with $1 \mu \mathrm{m}$ Fura-2/AM (Merck) in Krebs bicarbonate buffer ( $\mathrm{pH} 7.4$ ) containing $10 \mathrm{mM}$ glucose and $0.1 \%(\mathrm{w} / \mathrm{v}$ ) bovine serum albumin. Coverslips were analyzed on a monochromator-equipped (Polychrome IV, TILL-Photonics) inverted microscope (Axiovert 135, Zeiss). The fluorescence was recorded with a 12-bit CCD camera (IMAGO, TILLPhotonics) and TILLvision version 4.0 software. Fura-2 fluorescence was excited at 340,358 , and $380 \mathrm{~nm}$ and filtered through a Fura- 2 corresponding long-pass filter, and the $340 / 380$ fluorescence ratio was determined. $\beta$ Cells were identified based on cell size (83) and the characteristic calcium response to glucose (84).

Electrophysiology. Cell membrane potential was recorded in the current-clamp mode of the perforated-patch technique. The bath solution contained (in mM) $140 \mathrm{NaCl}, 5 \mathrm{KCl}, 1.2 \mathrm{MgCl}_{2}, 2.5 \mathrm{CaCl}_{2}, 15$ glucose, 10 HEPES, pH 7.4 adjusted with $\mathrm{NaOH}$. The pipette solution consisted of (in $\mathrm{mM}$ ) $10 \mathrm{KCl}, 10 \mathrm{NaCl}, 70 \mathrm{~K}_{2} \mathrm{SO}_{4}, 4 \mathrm{MgCl}_{2}, 2 \mathrm{CaCl}_{2}, 10$ EGTA, 10 HEPES, pH 7.15, adjusted with $\mathrm{KOH}$, and contained amphotericin $\mathrm{B}$ $(250 \mu \mathrm{g} / \mathrm{ml})$. Single-channel recordings were performed in the cellattached mode in a bath solution containing (in $\mathrm{mM}$ ) $130 \mathrm{KCl}, 1.2$ $\mathrm{MgCl}_{2}, 2 \mathrm{CaCl}_{2}, 10$ EGTA, 20 HEPES, $5 \mathrm{Na}_{2} \mathrm{ATP}$, pH 7.4, with KOH. Patch pipettes were pulled from borosilicate glass capillaries (Harvard Apparatus) and had resistances between 3 and $5 \mathrm{M} \Omega$ when filled with pipette solution (perforated-patch recordings) or 8 and $10 \mathrm{M} \Omega$ (cellattached mode). Membrane currents and potentials were recorded with an EPC-9 patch-clamp amplifier using Pulse software (HEKA). $\beta$ Cells were identified by cell size and their characteristic glucose dependence (83). Channel activity of the single channels was given as $N P_{o}$, determined as a product of open probability $\left(P_{o}\right)$ calculated by point-by-point analysis and the number of active channels in the patch $(N)$.

Statistics. Data are displayed as mean \pm SEM. $n$ indicates the number of animals per experimental group or the number of independent experiments. Comparisons between 2 groups were performed with unpaired $t$ test or ANOVA.

\section{Acknowledgments}

We thank Mark A. Magnuson for the RipCre line, Klaus Seuwen for the CaR antagonist NVP-CAR16, and Barbara Zimmermann for expert technical assistance.

Received for publication October 22, 2009, and accepted in revised form March 3, 2010.

Address correspondence to: Nina Wettschureck, Department of Pharmacology, Max-Planck-Institute for Heart and Lung Research, Ludwigstr. 43, 61231 Bad Nauheim, Germany. Phone: 49.6032.705.1214; Fax: 49.6032.705.1204; E-mail: Nina. Wettschureck@mpi-bn.mpg.de.
1. Kahn CR. Banting Lecture. Insulin action, diabetogenes, and the cause of type II diabetes. Diabetes. 1994;43(8):1066-1084.

2. Ashcroft FM, Harrison DE, Ashcroft SJ. Glucose induces closure of single potassium channels in isolated rat pancreatic beta-cells. Nature. 1984; 312(5993):446-448.

3. Cook DL, Hales CN. Intracellular ATP directly blocks $\mathrm{K}+$ channels in pancreatic B-cells. Nature. 1984;311(5983):271-273.

4. Robertson RP, Seaquist ER, Walseth TF. G proteins and modulation of insulin secretion. Diabetes. 1991;40(1):1-6

5. Emami S, et al. Stimulatory transducing systems in pancreatic islet cells. Ann N Y Acad Sci. 1998; 865:118-131.

6. Marie JC, Rosselin G, Skoglund G. Pancreatic beta-cell receptors and $G$ proteins coupled to adenylyl cyclase.
Ann N Y Acad Sci. 1996;805:122-131; discussion 132. 7. Islam MS, Larsson O, Nilsson T, Berggren PO Effects of caffeine on cytoplasmic free $\mathrm{Ca} 2+$ concentration in pancreatic beta-cells are mediated by interaction with ATP-sensitive $\mathrm{K}+$ channels and L-type voltage-gated Ca2 + channels but not the ryanodine receptor. Biochem J. 1995;306(pt 3):679-686.

8. Ammala C, Ashcroft FM, Rorsman P. Calciumindependent potentiation of insulin release by cyclic AMP in single beta-cells. Nature. 1993; 363(6427):356-358.

9. Holz GG 4th, Leech CA, Habener JF. Activation of a cAMP-regulated $\mathrm{Ca}(2+)$-signaling pathway in pancreatic beta-cells by the insulinotropic hormone glucagon-like peptide-1. J Biol Chem. 1995; 270(30):17749-17757.

10. Miller RE. Pancreatic neuroendocrinology: peripheral neural mechanisms in the regulation of the Islets of Langerhans. Endocr Rev. 1981;2(4):471-494.

11. Ahren B, Taborsky GJ Jr, Porte D Jr. Neuropeptidergic versus cholinergic and adrenergic regulation of islet hormone secretion. Diabetologia. 1986;29(12):827-836.

12. Boschero AC, et al. Oxotremorine-m potentiation of glucose-induced insulin release from rat islets involves M3 muscarinic receptors. Am J Physiol. 1995; 268(2 pt 1):E336-E342.

13. Duttaroy A, Zimliki CL, Gautam D, Cui Y, Mears D, Wess J. Muscarinic stimulation of pancreatic insulin and glucagon release is abolished in $\mathrm{m} 3$ muscarinic acetylcholine receptor-deficient mice. Diabetes. 2004;53(7):1714-1720.

14. Gautam D, et al. A critical role for beta cell M3 muscarinic acetylcholine receptors in regulating insulin release and blood glucose homeostasis in vivo. Cell Metab. 2006;3(6):449-461. 
15. Gilon P, Henquin JC. Mechanisms and physiological significance of the cholinergic control of pancreatic beta-cell function. Endocr Rev. 2001; 22(5):565-604.

16. Strathmann M, Simon MI. G protein diversity: a distinct class of alpha subunits is present in vertebrates and invertebrates. Proc Natl Acad Sci U S A. 1990;87(23):9113-9117.

17. Wilkie TM, Scherle PA, Strathmann MP, Slepak VZ, Simon MI. Characterization of G-protein alpha subunits in the Gq class: expression in murine tissues and in stromal and hematopoietic cell lines. Proc Natl Acad Sci U S A. 1991;88(22):10049-10053.

18. Exton JH. Regulation of phosphoinositide phospholipases by hormones, neurotransmitters, and other agonists linked to G proteins. Annu Rev Pharmacol Toxicol. 1996;36:481-509.

19. Regard JB, et al. Probing cell type-specific functions of $\mathrm{Gi}$ in vivo identifies GPCR regulators of insulin secretion. J Clin Invest. 2007;117(12):4034-4043.

20. Wettschureck N, Offermanns S. Mammalian G proteins and their cell type specific functions. Physiol Rev. 2005;85(4):1159-1204.

21. Winzell MS, Ahren B. G-protein-coupled receptors and islet function-implications for treatment of type 2 diabetes. Pharmacol Ther. 2007;116(3):437-448.

22. Itoh $Y$, et al. Free fatty acids regulate insulin secretion from pancreatic beta cells through GPR40. Nature. 2003;422(6928):173-176.

23. Verspohl EJ, Herrmann K. Involvement of G proteins in the effect of carbachol and cholecystokinin in rat pancreatic islets. Am J Physiol. 1996; 271(1 pt 1):E65-E72

24. Richardson SB, Laya T, VanOoy M. Similarities between hamster pancreatic islet beta (HIT) cell vasopressin receptors and $\mathrm{V} 1 \mathrm{~b}$ receptors. J Endocrinol. 1995;147(1):59-65.

25. Lee B, Yang C, Chen TH, al-Azawi N, Hsu WH. Effect of AVP and oxytocin on insulin release: involvement of V1b receptors. Am J Physiol. 1995; 269(6 pt 1):E1095-E1100.

26. Gregersen S, Thomsen JL, Hermansen K. Endothelin-1 (ET-1)-potentiated insulin secretion: involvement of protein kinase $\mathrm{C}$ and the $\mathrm{ET}(\mathrm{A})$ receptor subtype. Metabolism. 2000;49(2):264-269.

27. Parandeh F, Abaraviciene SM, Amisten S, Erlinge D, Salehi A. Uridine diphosphate (UDP) stimulates insulin secretion by activation of P2Y6 receptors. Biochem Biophys Res Commun. 2008;370(3):499-503.

28. Farret A, et al. P2Y receptor mediated modulation of insulin release by a novel generation of 2-substituted-5'-O-(1-boranotriphosphate)-adenosine analogues. Pharm Res. 2006;23(11):2665-2671.

29. Gray E, et al. Activation of the extracellular calcium-sensing receptor initiates insulin secretion from human islets of Langerhans: involvement of protein kinases. J Endocrinol. 2006;190(3):703-710.

30. Tremblay F, et al. Disruption of G protein-coupled receptor 39 impairs insulin secretion in vivo. Endocrinology. 2009;150(6):2586-2595.

31. Offermanns S, Zhao LP, Gohla A, Sarosi I, Simon MI, Wilkie TM. Embryonic cardiomyocyte hypoplasia and craniofacial defects in $\mathrm{G}$ alpha $\mathrm{q} / \mathrm{G}$ alpha 11-mutant mice. EMBO J. 1998;17(15):4304-4312.

32. Postic C, et al. Dual roles for glucokinase in glucose homeostasis as determined by liver and pancreatic beta cell-specific gene knock-outs using Cre recombinase. J Biol Chem. 1999;274(1):305-315.

33. Wettschureck $\mathrm{N}$, et al. Absence of pressure overload induced myocardial hypertrophy after conditional inactivation of Galphaq/Galpha11 in cardiomyocytes. Nat Med. 2001;7(11):1236-1240.

34. Lee JY, Ristow M, Lin X, White MF, Magnuson MA, Hennighausen L. RIP-Cre revisited, evidence for impairments of pancreatic beta-cell function. J Biol Chem. 2006;281(5):2649-2653.

35. Del Prato S. Loss of early insulin secretion leads to postprandial hyperglycaemia. Diabetologia. 2003;46(suppl 1):M2-M8.

36. Xu E, et al. Intra-islet insulin suppresses glucagon release via GABA-GABAA receptor system. Cell Metab. 2006;3(1):47-58.

37. Maruyama H, Hisatomi A, Orci L, Grodsky GM, Unger RH. Insulin within islets is a physiologic glucagon release inhibitor. J Clin Invest. 1984; 74(6):2296-2299.

38. Taylor SJ, Chae HZ, Rhee SG, Exton JH. Activation of the beta 1 isozyme of phospholipase $\mathrm{C}$ by alpha subunits of the Gq class of G proteins. Nature. 1991; 350(6318):516-518

39. Baukrowitz T, et al. PIP2 and PIP as determinants for ATP inhibition of KATP channels. Science. 1998 282(5391):1141-1144.

40. Shyng SL, Nichols CG. Membrane phospholipid control of nucleotide sensitivity of KATP channels. Science. 1998;282(5391):1138-1141.

41. Hutton JC, Penn EJ, Peshavaria M. Low-molecularweight constituents of isolated insulin-secretory granules. Bivalent cations, adenine nucleotides and inorganic phosphate. Biochem J. 1983;210(2):297-305

42. Gylfe E. Association between 5-hydroxytryptamine release and insulin secretion. J Endocrinol. 1978;78(2):239-248.

43. Fehmann HC, Weber V, Goke R, Goke B, Arnold R. Cosecretion of amylin and insulin from isolated rat pancreas. FEBS Lett. 1990;262(2):279-281.

44. Moran M. Prostaglandins and the release of insulin. A review and a proposal. Prostaglandins Lenkot Essent Fatty Acids. 1988;32(2):95-99.

45. Petit P, Lajoix AD, Gross R. P2 purinergic signalling in the pancreatic beta-cell: control of insulin secretion and pharmacology. Eur J Pharm Sci. 2009; 37(2):67-75.

46. Regard JB, Sato IT, Coughlin SR. Anatomical profiling of $G$ protein-coupled receptor expression. Cell. 2008;135(3):561-571.

47. Wollheim CB, Sharp GW. Regulation of insulin release by calcium. Physiol Rev. 1981;61(4):914-973.

48. Briscoe $\mathrm{CP}$, et al. The orphan $\mathrm{G}$ protein-coupled receptor GPR40 is activated by medium and long chain fatty acids. J Biol Chem. 2003;278(13):11303-11311.

49. Steneberg P, Rubins N, Bartoov-Shifman R, Walker MD, Edlund H. The FFA receptor GPR40 links hyperinsulinemia, hepatic steatosis, and impaired glucose homeostasis in mouse. Cell Metab. 2005;1(4):245-258.

50. Latour MG, et al. GPR40 is necessary but not sufficient for fatty acid stimulation of insulin secretion in vivo. Diabetes. 2007;56(4):1087-1094.

51. Alquier T, et al. Deletion of GPR40 impairs glucoseinduced insulin secretion in vivo in mice without affecting intracellular fuel metabolism in islets. Diabetes. 2009;58(11):2607-2615.

52. Verspohl EJ, Ammon HP, Williams JA, Goldfine ID. Evidence that cholecystokinin interacts with specific receptors and regulates insulin release in isolated rat islets of Langerhans. Diabetes. 1986;35(1):38-43.

53. Zawalich WS, Cote SB, Diaz VA. Influence of cholecystokinin on insulin output from isolated perifused pancreatic islets. Endocrinology. 1986; 119(2):616-621.

54. Karlsson S, Ahren B. CCKA receptor antagonism inhibits mechanisms underlying CCK-8-stimulated insulin release in isolated rat islets. Eur J Pharmacol. 1991;202(2):253-257.

55. Julien S, Laine J, Morisset J. The rat pancreatic islets: a reliable tool to study islet responses to cholecystokinin receptor occupation. Regul Pept. 2004; 121(1-3):73-81.

56. Bourassa J, Laine J, Kruse ML, Gagnon MC, Calvo $\mathrm{E}$, Morisset J. Ontogeny and species differences in the pancreatic expression and localization of the CCK(A) receptors. Biochem Biophys Res Commun. 1999; 260(3):820-828.

57. Simonsson E, Karlsson S, Ahren B. Islet phospholipase $\mathrm{A}(2)$ activation is potentiated in insulin resistant mice. Biochem Biophys Res Commun. 2000; 272(2):539-543.

58. Kilts JD, Lin SS, Lowe JE, Kwatra MM. Selective activation of human atrial Galpha12 and Galpha13 by Galphaq-coupled angiotensin and endothelin receptors. J Cardiovasc Pharmacol. 2007;50(3):299-303.

59. Sabbatini ME, Bi Y, Ji B, Ernst SA, Williams JA. CCK activates RhoA and Rac1 differentially through G\{alpha $\} 13$ and $G\{$ alpha\}q in mouse pancreatic acini. Am J Physiol Cell Physiol. 2009;298(3):C592-C601.

60. Xie T, Chen M, Zhang QH, Ma Z, Weinstein LS. Beta cell-specific deficiency of the stimulatory $\mathrm{G}$ protein alpha-subunit Gsalpha leads to reduced beta cell mass and insulin-deficient diabetes. Proc Natl Acad Sci U S A. 2007;104(49):19601-19606.

61. Fruman DA, Meyers RE, Cantley LC. Phosphoinositide kinases. Annu Rev Biochem. 1998;67:481-507.

62. Xie LH, Horie M, Takano M. Phospholipase Clinked receptors regulate the ATP-sensitive potassium channel by means of phosphatidylinositol 4,5bisphosphate metabolism. Proc Natl Acad Sci US A. 1999;96(26):15292-15297.

63. Best L, Malaisse WJ. Stimulation of phosphoinositide breakdown in rat pancreatic islets by glucose and carbamylcholine. Biochem Biophys Res Commun. 1983; 116(1):9-16.

64. Zawalich WS, Zawalich KC, Rasmussen H. Cholinergic agonists prime the beta-cell to glucose stimulation. Endocrinology. 1989;125(5):2400-2406.

65. Nakano K, et al. Intracellular $\mathrm{Ca}(2+)$ modulation of ATP-sensitive $\mathrm{K}(+)$ channel activity in acetylcholine-induced activation of rat pancreatic beta-cells. Endocrinology. 2002;143(2):569-576.

66. Arkhammar $\mathrm{P}$, et al. Protein kinase $\mathrm{C}$ modulates the insulin secretory process by maintaining a proper function of the beta-cell voltage-activated $\mathrm{Ca} 2+$ channels. J Biol Chem. 1994;269(4):2743-2749.

67. Wolf BA, Florholmen J, Turk J, McDaniel ML. Studies of the $\mathrm{Ca} 2+$ requirements for glucoseand carbachol-induced augmentation of inositol trisphosphate and inositol tetrakisphosphate accumulation in digitonin-permeabilized islets. Evidence for a glucose recognition site in insulin secretion. J Biol Chem. 1988;263(8):3565-3575.

68. Biden TJ, Peter-Riesch B, Schlegel W, Wollheim CB. Ca2+-mediated generation of inositol 1,4,5-triphosphate and inositol 1,3,4,5-tetrakisphosphate in pancreatic islets. Studies with $\mathrm{K}^{+}$, glucose, and carbamylcholine. J Biol Chem. 1987;262(8):3567-3571.

69. Montague W, Morgan NG, Rumford GM, Prince CA. Effect of glucose on polyphosphoinositide metabolism in isolated rat islets of Langerhans. Biochem J. 1985;227(2):483-489.

70. Prentki M, Matschinsky FM. Ca2+, cAMP, and phospholipid-derived messengers in coupling mechanisms of insulin secretion. Physiol Rev. 1987; 67(4):1185-1248

71. Hedeskov CJ, Thams P, Gembal M, Malik T, Capito K. Characteristics of phosphoinositide-specific phospholipase $\mathrm{C}$ activity from mouse pancreatic islets. Mol Cell Endocrinol. 1991;78(3):187-195

72. Hazama A, Hayashi S, Okada Y. Cell surface measurements of ATP release from single pancreatic beta cells using a novel biosensor technique. Pflugers Arch. 1998;437(1):31-35.

73. Kreda SM, et al. Coordinated release of nucleotides and mucin from human airway epithelial Calu-3 cells. J Physiol. 2007;584(pt 1):245-259.

74. Kreda SM, Seminario-Vidal L, Heusden C, Lazarowski ER. Thrombin-promoted release of UDPglucose from human astrocytoma cells. $\mathrm{Br} \mathrm{J} \mathrm{Phar-}$ macol. 2008;153(7):1528-1537.

75. Tatur S, Groulx N, Orlov SN, Grygorczyk R. Ca2+dependent ATP release from A549 cells involves synergistic autocrine stimulation by coreleased uridine nucleotides. J Physiol. 2007;584(pt 2):419-435.

76. Farret A, Vignaud M, Dietz S, Vignon J, Petit P, Gross R. P2Y purinergic potentiation of glucose- 
induced insulin secretion and pancreatic beta-cell metabolism. Diabetes. 2004;53(suppl 3):S63-S66.

77. Chevassus $\mathrm{H}$, et al. $\mathrm{P} 2 \mathrm{Y}$ receptor activation enhances insulin release from pancreatic beta-cells by triggering the cyclic AMP/protein kinase A pathway. Naunyn Schmiedebergs Arch Pharmacol. 2002;366(5):464-469.

78. Fischer B, et al. 2-thioether 5'-O-(1-thiotriphosphate) adenosine derivatives as new insulin secretagogues acting through P2Y-Receptors. J Med Chem. 1999;42(18):3636-3646.

79. Fernandez-Alvarez J, Hillaire-Buys D, LoubatieresMariani MM, Gomis R, Petit P. P2 receptor agonists stimulate insulin release from human pancreatic islets. Pancreas. 2001;22(1):69-71.

80. Petit P, Bertrand G, Schmeer W, Henquin JC. Effects of extracellular adenine nucleotides on the electri$\mathrm{cal}$, ionic and secretory events in mouse pancreatic beta-cells. BrJ Pharmacol. 1989;98(3):875-882.

81. Poulsen CR, et al. Multiple sites of purinergic control of insulin secretion in mouse pancreatic beta-cells. Diabetes. 1999;48(11):2171-2181.

82. Kitsou-Mylona I, Burns CJ, Squires PE, Persaud SJ, Jones PM. A role for the extracellular calciumsensing receptor in cell-cell communication in pancreatic islets of langerhans. Cell Physiol Biochem. 2008;22(5-6):557-566.

83. Leung YM, et al. Electrophysiological characterization of pancreatic islet cells in the mouse insulin promoter-green fluorescent protein mouse. Endocrinology. 2005;146(11):4766-4775.

84. Asada N, Shibuya I, Iwanaga T, Niwa K, Kanno T. Identification of alpha- and beta-cells in intact isolated islets of Langerhans by their characteristic cytoplasmic Ca2+ concentration dynamics and immunocytochemical staining. Diabetes. 1998; 47(5):751-757. 